\title{
Legal Liability for Selling Medicines Online in Turkish Law
}

\author{
Dr. Mehmet Akçaal ${ }^{\text {पu }}$
}

\begin{abstract}
Selling medicines online or in any other electronic form is not allowed in Turkish law. Because the sale of medicines (or medicinal product) online is a distance sale contract in the eye of law, such contract will be null and void. For that reason, victims are not entitled to any claim under the distance sales contract concluded with their supplier in Turkish law. However, the victims and other persons in the distribution chain can bring an action based on tort against the supplier. This article analyses the legal principles of civil liability for the sale of medicine online in the first place. Secondly, it explains whether it is possible to protect consumers who have bought a medicinal product online. Thirdly, it describes the protection of owners of pharmaceutical trademarks because of the online sale of their products without their permission. Finally, it sheds light on the criminal liability of the online sale of medicines in Turkish criminal law.
\end{abstract}

KEYWORDS: Law of health, Legal liability, Medicine, Sales of medicine online, Absolute nullity.

$\square \quad$ The basic of this study is a piece of a project called as ALPhA (Auswirkungen der Liberalisierung des Internethandels in Europa auf den Phänomenbereich der Arzneimittelkriminalität).

प्र Research Assistant, Faculty of Law, Selçuk University, Konya, Turkey 


\section{INTRODUCTION}

Medicine is an indispensable product for human life. Medicine law is a new discipline in Turkish law. Although the issue of criminal and legal liability for the online sale of medicines is a current topic in the Turkish legal system, it has not been thoroughly analyzed so far. There are only a few judgments regarding the criminal liability, but these are related to the sale of unlicensed medicines. The issue of criminal liability for the online sale of medicines has not been discussed in the literature.

\section{CIVIL LIABILITY A) LIABILITY FOR SELLING MEDICINES ONLINE 1) Conditions of Liability for Selling Medicines Online}

Selling medicine online is prohibited according to Act about the Pharmacists and Pharmaciesr no 6197 in Turkish law. The Article 24, 1 st paragraph, 3 rd and 4 th sentence of the Act state that: "the medicines cannot be sold online or in any other electronic form. Websites cannot be set up in the name of pharmacists and pharmacies". So selling medicine online is unlawful in the Turkish legal system.

Since distance online sale contracts regarding medicinal products are null and void from the moment that they were made, the victims and other persons in the distribution chain are not entitled to any claim under the distance sales contracts concluded with their supplier in Turkish law. A contract that is null and void does not give any right to the parties. However, the party who has performed the contract may demand restitution based on the provisions regarding unjust enrichment (C. O. Arts. 77-82) from the other partyr. Victim can also demand compensation because of the null and void online sales contract for medicine on the basis of liability for "culpa in contrahendo" if the other party has fault ${ }^{*}$.

Moreover, the victim and other persons in the distribution chain can bring an action against their supplier on the basis tort due to the fact that their rights of personality are infringed. When the medicines are sold on internet, victim can demand damages according to provisions related to the tort liability (C. O. Arts. 49-76). The conditions which are necessary to hold

1 But the issue of criminal liability for selling medicine has been vastly analysed in the literature. See Altunkaş, Aysun: Kişilerin Hayatını ve Sağlığını Tehlikeye Sokacak Biçimde İlaç Yapma veya Satma Suçu

(TCK m. 187), Marmara Üniversitesi Hukuk Fakültesi Hukuk Araştırmaları Dergisi, 2013/II, p. 829-870;

Koca, Mahmut: Illaç Kullanımından Doğan Zararlardan Cezai Sorumluluk, Illaç Hukuku, Editörler: Murat Şen

/ Ahmet Başözen, Erciyes Üniversitesi I. Sağlık Hukuku Sempozyumu, 08-09 Mayıs 2009, Kayseri, p. 321359; Döner, İsa: İlaç Sahtekarlığı Suçları (TCK m. 186 - TCK m. 187), illaç Hukuku, (eds.) Murat Şen / Ahmet Başözen, Erciyes Üniversitesi Hukuk Fakültesi I. Sağlık Hukuku Sempozyumu, 08-09 Mayıs 2009, Kayseri, p. 361-389; Doğan, Cahid: İlaç Kullanımı Dolayısıyla Ortaya Çıkan Zararlardan Cezai Sorumluluk, II. Sağlık Hukuku Kurultayı, 7-8 Kasım 2008 Ankara, Ankara Barosu Yayınları, 2009, p. 411-454; Çakmut, Özlem Yenerer: Taklit - Sahte illaç Kavramı ve Türk Ceza Yasası'nda illaç Sektörünü ilgilendiren Suçlar (TCK m. 186187), i̇laç Hukuku ve Etik Anlayışı, Sempozyum No: 2, Marmara Üniversitesi, 01 Haziran 2007, p. 126150.

2 Official Journal, No. 8591, Date, 24.12.1953.

3 See Honsell, Heinrich / Vogt, Peter Nedim / Wiegand, Wolfgang: Basler Kommentar, Obligationenrecht I Art. 1-519 OR, 6th Edition, Basel 2015, p. 195 et seq. ${ }^{4}$ See Honsell / Vogt / Wiegand, p. 20 et seq. 
supplier responsible for tort are unlawful action, fault, damage and causality. First of all, contradiction to law is necessary to compensate the material damages. Otherwise, the act will be legal according to the law. Material damage must occur because of contradiction to law. If there is no material damage, action for damages cannot be brought. An unlawful act is necessary to bring an action for material damages. Omissions may also be adequate for an unlawful action. The defendant must have fault; whether it is intent to an act or negligence does not matter. If there is a tort, the injured party (victim) has to prove that the other party (tortfeasor) has negligence at least'.

Ineffectiveness of a medicinal product constitutes a basis for such a liability if damage occurs, ineffectiveness of a medicinal product is identical to the effectiveness of a medicinal product ${ }^{r}$. Thus, the pharmacist or the seller should be responsible for the ineffectiveness of a medicinal product. The Court of Appeal states that if the medicine does not benefit patients, the producer has to compensate the damage of patient. Art. 18 of Act related to the Pharmacy and Medical Medicament $^{r}$ no 1262 regulates administrative fines for ineffectiveness of a medicinal product.

\section{2) Protected Persons}

Anyone who suffers damage because of the online sale of medicines is within the scope of protection of the Turkish Civil Code ${ }^{\uparrow}$ no 4721 and the Code of Obligations ${ }^{\Delta \varphi}$ no 6098. Because rights of personality involve life, bodily integrity and health as well $\ldots$.. Act against rights of personality sets an example for tort. As a rule, anyone who suffers damage because of the online sale of medicine is protected under Articles 24-25 of the Turkish Civil Code and

\footnotetext{
${ }^{1}$ Schönenberger, Wilhelm / Gauch, Peter: Schweizerisches Obligationenrecht, 38th Edition, Zürich 1990, p. 10 et seq.; Honsell / Vogt / Wiegand, p. 321 et seq.; von Tuhr, Andreas: Borçlar Hukukunun Umumî Kısmı (Translator: Cevat Edge), Vol.: 1-2, 2th Edition, Ankara 1983, p. 361 et seq.; Tandoğan, Halûk: Türk Mes'uliyet Hukuku, 2 th Edition, İstanbul 2010, p. 3 et seq.; Eren, Fikret: Borçlar Hukuku Genel Hükümler, 22th Edition, Ankara 2017, p. 538 et seq.; Oğuzman, M. Kemal / Öz, M. Turgut: Borçlar Hukuku Genel Hükümler, Vol: 2, 12th Edition, İstanbul 2016, p. 11 et seq.; Akıntürk, Turgut / Ateş Karaman, Derya: Borçlar Hukuku, Genel Hükümler, Özel Borç İlişkileri, 20th Edition, İstanbul 2013, p. 87 et seq.; Reisoğlu, Safa: Borçlar Hukuku, Genel Hükümler, 23th Edition, İstanbul 2012, p. 163 et seq. Kılıçoğlu, Ahmet M.: Borçlar Hukuku, Genel Hükümler, 17th Edition, Ankara 2013, p. 273 et seq. Akıncı, Şahin: Borçlar Hukuku Bilgisi, Genel Hükümler, 10th Edition Konya 2017, p. 136 et seq.; Antalya, O. Gökhan: Borçlar Hukuku, Genel Hükümler, Vol.: 1, İstanbul 2013, p. 419 et seq.

${ }^{2}$ Akçaal, Mehmet: 6098 Sayılı Türk Borçlar Kanunu Çerçevesinde İlaç Üreticisinin Hukuki Sorumluluğu, Ankara Barosu Dergisi, 2012/3, p. 282; Turkish Court of Appeal 4th Civil Chamber, Date: 27.4.2009, No: 2008/10142, 2009/5958 (КBiBB.).

${ }^{3}$ Official Journal, No. 898, Date, 26.5.1928.

${ }^{4}$ Official Journal, No. 24607, Date, 8.12.2001.

${ }^{5}$ Official Journal, No. 27836, Date, 04.02.2011.

${ }^{6}$ There is no general clause according to which any loss may be covered or a catalogue of the protected ${ }^{0}$ rights. The rights are not stated clearly in any code. So judges are obliged to define in accordance with Article 4 of the Turkish Civil Code no 4721 whether it is a personality right or not. See Dural, Mustafa / Öğüz, Tufan: Türk Özel Hukuku, Kişiler Hukuku, Vol.: 2, 10 th. Edition, İstanbul 2010, p. 94 et seq.;

Oğuzman, M. Kemal / Seliçi, Özer / Oktay-Özdemir, Saibe: Kişiler Hukuku, Gerçek ve Tüzel Kişiler, 12th Edition, İstanbul 2012, p. 153 et seq.; Akipek, Jale G. / Akıntürk, Turgut / Ateş Karaman, Derya: Türk Medeni Hukuku, Vol.: 1, 9th Edition, İstanbul 2012, p. 341 et seq.
} 
Article 49 of the Code of Obligations. Victims can demand material and moral damages when the medicine harms them. Material damages which can be demanded from other party are actual material damages and loss of profits.

Moreover, when the bodily harm is serious or the victim is death, persons who have close ties with the victim can demand their own moral damages, as well $॥$. Persons who are deprived of support of the deceased person can demand their own material damages the tortfeasor in accordance with the Art. 53/3 of the Code of Obligations no 6098. They can also demand funeral expenses, medical treatment expenses and losses related to the workforce (Art. 53/1-2). All these provisions aim to protect the personality of victim.

\section{3) The Burden of Proof of the Conditions of Liability}

Party in breach is the obliged party according to the contractual provisions. As a rule there must be a contract between parties in order to implement the contractual provisions. When the counterfeit medicinal products are produced or sold by a pharmacist, she/he is responsible according to the contractual provisions. In this regard, the pharmacist has to prove that she/he has no fault. Otherwise, the pharmacist has to compensate the material and moral damages of patient.

On the other hand, when the medicine is sold online, victim can demand compensation for the damage according to provisions related to the tort liability (C. O. Arts. 49-76). If there is a tort, victim carries the burden of proof about the conditions of liability for an action for damages. Victim has to prove that the other party has negligence at the very least. Victim has to prove that she/he suffers damage. Moreover victim has to prove that there is a causalityir.

Selling medicine online is not a type of strict liability. As the victim carries the burden of proof of the conditions of liability, the liable party can be exempted from the liability when the victim cannot prove the conditions of the tort liability.

\section{4) The Legal Consequences of Civil Liability Because of Internet Based Medicines}

The judge renders a judgment in-kind or in cash in an action for material damages. But when an attack against right of personality occurs exactly compensation is not possible generally. So the judge renders a judgment in cash in an action for material damages ir.

The judge sets the type of compensation (C. O. Art. 53/I). Award of damages is the general consequence of an action for moral damages.

\footnotetext{
${ }^{1}$ Persons who can demand their own moral damages from court were the family of dead person in ${ }^{1}$ accordance with the previous Code of Obligation no 818. But the scope of persons is expanded with the Code of Obligation no 6098. Thus fiancée or even another person who have emotionally close ties with her/his can even demand their own moral damages. Person demanding damages need not to be a part of his/her family. See Oğuzman / Öz, p. 285; Akıncı, p. 182, fn. 194; Keskin, A. Dilşad: Objektif Manevi Zarar Teorisi Açısından Manevi Tazminat, Ankara 2016, p. 258 et seq.
} 
1 Guhl, Theo: Das Schweizerische Obligationenrecht, 3th Edition, Zürich 1944, p. 135; Tekinay, Selahattin S. ${ }^{2}$ / Akman, Sermet / Burcuoğlu, Haluk / Altop, Atilla: Borçlar Hukuku, Genel Hükümler, 7th Edition, İstanbul 1993, p. 576; Eren, p. 746.

1 Tekinay / Akman / Burcuoğlu / Altop, p. 581; Eren, p. 796 et seq.; Akıncı, p. 179. ${ }^{3}$

There is no particular maximum limit on the amount of damages. But compensation cannot exceed material damages and moral damages. Moreover moral damages have to be paid at a timeıs.

On the other hand, the contributory negligence of the patient is taken into consideration in Turkish law in accordance with the Article 52/I of the Code of Obligations (C. O.) no 6098. The Article 52/I states that while judge is setting the amount of compensation, she/he also takes into consideration contributory negligence of the aggrieved person, as well. If the patient has contributed to the damage, the judge can reduce the amount of compensation or reject it in its entirely (Art. 52/I). The condition for the contributory negligence to be taken into consideration is aggrieved person to be effective about the rising of damage or increasing of it. So the contributory negligence is taken into consideration in case law by judges as well ${ }^{1 \Delta}$. The Court of Appeal states that defendants (hospital and the doctor) are responsible for all the damages as the plaintiffs (parents) has no contributory negligence about the loss of eyes of their premature born baby. The judge can only make a reduction about the amount of compensation in accordance with the Article 51 and 52 of the Code of Obligations 19.

The competent court is determined in accordance with the Civil Procedure Act no 6100 in the case of tort liability. In this respect, actions related to torts can be brought before the court where the defendant has the domicile (Art. 6/I). Also, these action can be brought before the court where the tortious act is committed or the damage occurs or the plaintiff has the domicile, too (Article 16). If the plea as to jurisdiction is not offered by the defendant related to action about the tort, the action is even adjudicated by unauthorized court, too (Art. 19).

Article 73/6 of Act on the Protection of Consumers iv no 6502 states that consumer organizations, relevant public authority, relevant public organizations and relevant ministry can bring a declaratory judgment action, action for prevention and action for prohibition in consumer court if a dispute occurs related to the consumers.

\section{5) The Importance for the Claims Whether the Medicine Itself Only or Its Packaging Were Subject To Changes}

There is a classification for the error concept relating to responsibility of medicine producer. Warning error is one of them. Responsibility for the warning error is grounded on the error for ticketing of medicine packing and using information for the patients or specialization information for the pharmacist or doctor. The medicine producer is responsible for the declared registration of medicine and the damages because of using the medicine on the scopes that are shown on prospectus $\backslash$. 
1 Eren, p. 746 et seq.; Akıncı, p. 179 et seq. ${ }^{4}$

1 Turkish Court of Appeal 4th Civil Chamber, Date: 13.3.2014, No: 2013/7109, 2014/4354; Turkish Court ${ }^{5}$ of Appeal 3rd Civil Chamber, Date: 19.2.2015, No: 2014/9630, 2015/2567 (KBiBB.).

1 Turkish Court of Appeal 13rd Civil Chamber, Date: 26.10.2004, No: 2004/6493, 2004/15431 (KBiBB.). ${ }^{6}$

1 Official Journal, No. 28835, Date, 28.11.2013. ${ }^{7}$

1 Akçaal, p. 277.

Compensation due to erroneous packaging can be demanded from the pharmacist 19. But, it must be taken into consideration that the pharmacist is liable for tort. She/he has to be fault to compensate the damage. But selling medicine online is prohibited in Turkish law. There is no binding contract between victim and pharmacy or anyone who sells medicines on internet. So, seller is obliged to compensate damage of the other party because of medicines packaging on the basis of tort if it is sold on internet.

\section{B) LIABILITY OF THE MANUFACTURER OF THE ORIGINAL DUE TO SALE OF MEDICINE ONLINE}

Turkey is a candidate country for European Union membership. In this regard many laws have entered into force in Turkey to harmonise the national legislation with that of the EU. An act which is appropriate to the Directive 2011/62/EU was expected to enter into force in Turkey in the second half of 2015, but the legal norms have not been adopted since then.

On the other hand the By-Law about the Factories for the Human Medicinal Product is in force. But there is not any specific legislation relating to this issue that would form basis of liability of the manufacturer of the original.

There is neither a code regarding the liability of producers nor a special medicine code in Turkish law. So the issue is controversial in the literature, too. Besides, the Code of Obligations no 6098 entered into force in 1 July 2012. The liability for danger is put in order in the Code of Obligations no 6098 with a general provision (Art. 71). So according to a commentator in the doctriner. the victim can bring an action based on the liability for danger. Out of ordinary and uncontrolled danger which is a particular type of concept of general danger characterizes the responsibility of the producer of mediciners. On the other side, there is no particular regulation related to the responsibility of producer of medicine in Turkish law. But there is a general provision for the liability of danger in the Code of Obligation (Article 71). So the liability of danger which is regulated generally in the Code of Obligations no 6098 can be accepted as the legal basis for the responsibility of producer of medicinerr.

The liability for danger is a type of the strict liability. The basic condition for the liability for danger is danger to be the reason for damage by occurring characteristic danger of an object, activity or enterpriserr. Whether the liable party has fault is not important related to the compensation for the liability of dangerre. The first condition of liability for danger is the existence of a value under the threat of danger which is highly probable to realize. Second

1 Doğan, Murat: Eczacının Tazminat Sorumluluğu, (http://www.kazanci.com/kho2/hebb/files/makale ${ }^{9}$ muratdogan-9.htm.), (Date of Access:12.5.2015). 
2 See Akkanat, Halil: İlaç Kullanımından Kaynaklanan Zararlardan Sorumluluk Açısından $\mathrm{Hasta}^{0}{ }^{-H_{e}}$ kim- $^{-}$

Üretici İlişkileri, Erciyes Üniversitesi Hukuk Fakültesi, I. Sağıık Hukuku Sempozyumu, 08-09 Mayıs 2009 Kayseri, Vol. 1, No. 1, p. 75 et seq.

2 See Petek, Hasan: İlaç Üreticisinin Hukuki Sorumluluğu, Ankara 2009, Pp. 89. ${ }^{1}$

2 See Başpınar, Veysel: İlaç Üreticisinin Hukuki ${ }^{2}$ Sorumluluğu, illaç Hukuku, Erciyes Üniversitesi Hukuk Fakültesi I. Sağlık Hukuku Sempozyumu 8-9 Mayıs 2009-Kayseri, Vol. 1. No. 1, p. 85 et seq.

2 See Yücel, Özge: Türk Borçlar Kanununa Göre Genel Tehlike Sorumluluğu, Ankara 2014, p. 114 Eren, p. ${ }^{3} 689$.

${ }^{2}$ See Tiftik, Mustafa: Tehlike ${ }^{4}$ Sorumluluğunun Ayırıcı Özellikleri ve Türk Hukukunda Tehlike Sorumluluklarının Genel Kural ille Düzenlenmesi Sorunu, Erzurum 1997, Pp. 34.

condition is the danger to violate this value by realizing. Finally, damage to occur because of this reason is the last condition for liability for danger.

If the damaged party brings an action based on the liability for danger (Art. 71), she/he needn't prove fault of manufacturer. But the conditions which are necessary to hold manufacturer responsible for this type of claim are unlawful action, damage and causal connection. The damaged party has to prove all of these conditions (unlawful action, damage and causal connection).

\section{POSSIBILITY OF PROTECTION OF CONSUMERS BUYING A MEDICINAL PRODUCT ONLINE BECAUSE OF THE LEGISLATION RELATED TO THE CONSUMERS A) LIABILITY IN CASE OF LOSSES CAUSED BY THE USAGE OF FALSIFIED MEDICINAL PRODUCTS}

Article 4 of abrogated the Act on the Protection of Consumers rs no 4077 was amended $r$ in

2003 appropriate to the Directive 85/374/EEC. So Turkey has adopted the directive 85/374/EEC on the approximation of the laws, regulations and administrative provisions of the Member States concerning liability for defective products. But the Act on the Protection of Consumers no 6502 has entered into force instead of Act no 4077. However manufacturer's liability is not regulated in the Act no 6502, too. Manufacturer's liability is regulated in the ByLaw Related to the Responsibility for the Damages Related to the Defective Good rv in parallel with the Directive 85/374/EEC. The conditions of manufacturer's liability are product to be defective, damage to occur, contradiction to law and causal link between the defectiveness and the damage. Manufacturer has to compensate the damage without the need for her/his fault if the defective good is reason for a person to die or to be injured or a good to damage (Article $6 / I$ of the By-Law). The victim has to prove the defect of the good, the damage and the causal link between the defect and the damage (Article 6/II of the By-Law).

If two or more persons are responsible because of the damage of the defective good they are all liable jointly (Article 6/III of the By-Law). Contractual provisions for non-liability related to the waiver of consumer's rights or contractual provisions for restriction or termination the obligations of manufacturers derived from this By-Law are invalid (Article 8 of the By-Law). All types of demands due to damage of the defective good are subject to the limitation period of three years starting from the date the defendant learned the defect and manufacturer (Article 9 of the By-Law). Claims for compensation against all types of damages because of defective good can be asserted in ten years beginning from the date of introducing to the market of the injurious good (Article 10 of the By-Law). 
Moreover when the counterfeit medical products are sold online, the victim can demand the damage according to provisions related to the tort liability (C. O. 49-76). If there is a tort,

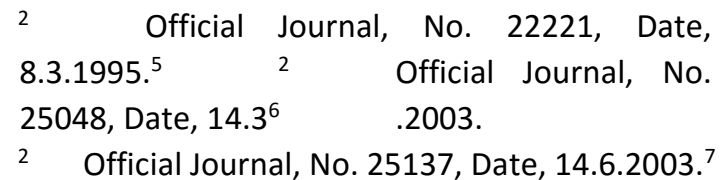

victim has to prove that the other party has negligence at least $r$. As the selling medicine online is not a type of strict liability.

\section{B) POSSIBILITY OF RIGHT OF WITHDRAWAL}

Turkey has adopted the Directive on Consumer Rights 2011/83/EC that introduces the full harmonization of the right of withdrawal with the Act on the Protection of Consumers no 6502. Distance contracts are regulated in the Act on the Protection of Consumers no 6502 in conformity with the Directive 2011/83/EC. The Article 48, 1 st paragraph of the Act no 6502 states: "Consumer has the withdrawing right for the contract in fourteen days without paying the penalty clause and needn't any reason for it".

But consumers cannot buy a medicinal product online with a right of withdrawal according to the Turkish law, as the medicines cannot be sold via internet or in any other electronic form. A distance contract via online for a medicinal product is null and void from the beginning. On the other hand consumers have the possibility to have their money back on the basis of the unjust enrichment on the part of the seller in accordance with the Code of Obligations no 6098. Because the obligation of the restitution arises if the enrichment is based on an invalid reason (C. O. Art. 77/II) rq.

\section{PROTECTION OF THE OWNERS OF THE PHARMACEUTICAL TRADEMARKS BECAUSE OF THE SALE OF TRADEMARKED MEDICINES ON INTERNET WITHOUT THEIR PERMISSION A) GENERALLY}

To be able to adapt the Turkish Intellectual Property Law with EU, 7 th Chapter which is named as "Law of Intellectual Property" is opened to negotiation with the letter of EU Presidency in 16 th April 2008. In this regard Directive 2004/48/EC is one of the directives which is foreseen to be adopted into Turkish law in 2016. So Turkey has not adopted the IP Rights Enforcement Directive 2004/48/EC or any other EU legislation in the scope of the intellectual property law yet.

However registered pharmaceutical trademarks are protected according to the Act on the Industrial Propertyr. no 6769. Owner of a registered trademark can bring an action for prevention, declaratory judgment action, action for prohibition and action for damages against the persons who sell the trademarked medicines without permission (Art. 149/I). Action for prevention, action for prohibition and declaratory judgment action can be sued even if the defendant does not have fault. However, defendant has to have fault to be able to sue the action 
for damages $r$. However, defendant has to have fault to be able to sue the action for damages. Internet service provider is accepted as fault when she/he does not

2 Tekinay / Akman / Burcuoğlu / Altop, p. 577; Akıncı, p. $153 .^{8}$

Oğuzman / Öz, p. 321.

9

Official Journal, No. 29944, Date, 10.1.2017. ${ }^{\circ}$

See Arkan, Sabih: Ticari İşletme Hukuku, 17th Edition, Anka ${ }^{1}$ ra 2012, Pp. 300.

remove unlawful issue from website in spite of a notice which is given by the competitor. The Court of Appeal shares the same opinion with the doctrinerr.

Moreover the owner of a registered trademark can sue for seizing the medicine or other objects related to the infringement of the trademark. The owner of the registered trademark can demand to be assigned property of the products which are seized. Crossing off the trademark or destruction of medicine can be demanded by the owner of trademark if it is inevitable for preventing the infringement of registered trademark (Art. 149/I,f)rr.

On the other hand unregistered pharmaceutical trademarks are protected according to the general provisions of the Turkish Commercial Code no 6102. In this regard, provisions (Art. 54-63) related to unfair competition in the Turkish Commercial Code are applicable for unregistered pharmaceutical trademarks. Any behavior or business practice that is misleading or in any other way infringes the principle of good faith shall be deemed as unfair and unlawful in accordance with Article 54/II of the Turkish Commercial Code no 6102. The other condition of unfair competition is damage or danger of damage. There is no unfair competition if the damage or danger of damage does not occur as a result of the act. Third condition for unfair competition is the casual link between the damage and the misleading behaviors or commercial practices. On the other hand fault is not a condition for unfair competition. But offender has to have fault to be able to be brought action for damage because of unfair competitionrf.

The owner of an unregistered pharmaceutical trademark can bring an action for prevention, declaratory judgment action, action for prohibition and action for damages against the persons who sell the trademarked medicines without permission (Art. 56). The owner of an unregistered trademark can sue for seizing the medicine or other objects related to the infringement, too (Art. 56/I, c) rه.

\section{B) PROTECTION OF COMPETITORS AGAINST SELLING COPIED MEDICINES ON INTERNET}

Any behavior or business practice that is misleading or in any other way infringes the principle of good faith shall be deemed as unfair and unlawful in accordance with Article 54/II of the Turkish Commercial Code no 6102. The situations which constitute unfair competition are regulated in Article 55 of the Turkish Commercial Code no 6502. These situations are not limited. So competitors can demand protection against copying in accordance with unfair competition as above mentioned (Article 54-63). Because obtaining advantageous position for 
himself/herself any other third party by making unreal or misleading statements is contrary to the principle of good faith, too (Article 55/I, a. 2). Moreover trying to create the assumption of owner of superior talent even though he/she does not have any decree, certificate and award or to use incorrect occupational names or symbols constitutes unfair competition, too (Article 55/I, a, 3). The Court of Appeal states that selling copied products constitutes unfair competition and compensation can be demanded by

3 The Court of Appeal, Civil Assembly, Date: 15.1.2014, No: ${ }^{2} 2013 / 11-1138,2014 / 16$ (KBIBB.).

See Baş, Başak: İlaçta Zorunlu Patent Lisansı, Ankara Barosu Dergisi, Vol. 69, No. 3, Y. 2011, p. 105 et seq. ${ }^{3}$

See Arkan, p. 314 et seq. ${ }^{4}$

See Arkan, p. 273 et seq. ${ }^{5}$

plaintiffrs. The owner of a copied product can bring an action for prevention, declaratory judgment action, action for prohibition and action for damages (Art. 56). The owner of a trademark can sue for seizing the medicine or other objects related to the infringement, too (Art. 56/I, c).

Firstly plaintiff can be the persons who are affected because of unfair competition in accordance with Article 58/I. These persons can sue for all actions mentioned in Article 56. Secondly customers can bring the all above mentioned actions if they suffer damage or experience the danger of damage economically because of unfair competition. But customers cannot demand seizing the medicine or other objects related to the infringement (Article 56/II). Thirdly vocational and economical associations, public authorities and nongovernmental organizations can bring a declaratory judgment action, action for prohibition or can demand seizing elements related to the infringement (Article 56/III). However they cannot bring an action for compensation rv.

Moreover patent grants a monopoly right to the owner for producing, using and importing the invention which is subject of patent according to the Act on the Industrial Property no 6769 (Art. 85/II). Producers of registered medicines can prevent invention-oriented impingement of third parties by courtesy of protection of patent. They can prevent third parties from producing of chemical formula which are qualified as invention, selling, using, importing and holding medicines for any other reasons (Art. 85/II) rᄉ.

\section{CRIMINAL LIABILITY A) GENERALLY}

As above mentioned, sales contract for medicine via internet is contrary to law according to Act about the Pharmacists and Pharmacies no 6197 in Turkish law (Art. 24/I, s. 3, 4). The medicines are not allowed to be sold online or in any other electronic form. Setting up a website in the name of pharmacists and pharmacies is prohibited. Criminal liability occurs in case of fulfillment of the conditions of liability. Moreover, the Art. 43, 1 st paragraph of the Act no 6197 states: "Selling toxic and chemical substances or medical medicament and preparations without permission is prohibited. Anyone who sells these without permission or holds these in the pharmacy shop to sell is sentenced according to Art. 193 of the Turkish

Criminal Code". Art. 193 of the Turkish Criminal Code ${ }^{r q}$ states: "Whoever who produces, holds, sells or transfers substance that involves poison and depends on permission to produce, 
to hold or to sell without permission shall be sentenced to a prison sentence of two months to one year"s.

\section{B) THE CRIMINAL LIABILITY FOR THE COUNTERFEITED MEDICINES}

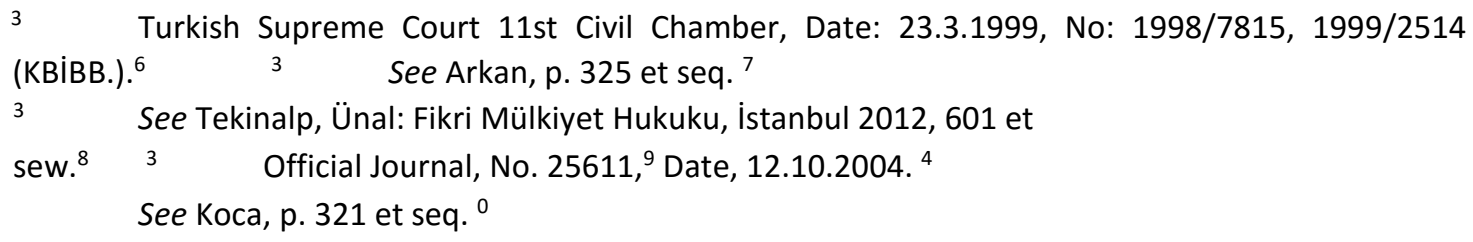

Counterfeited medicines and imitation medicine are the terms which are defined in Turkish civil law doctriner. On the other hand the issue of the liability of the manufacturer of the original medicinal product for counterfeited medicines has not been widely discussed in the literature r. But the criminal liability about this issue is regulated in the Turkish Criminal

Code. Article 187 of the Turkish Criminal Code states: "Anyone who produces or sells medicine by placing at risk persons' life and health is sentenced to imprisonment for one year to five years and judicial fine. If the crime is committed by a doctor, a pharmacist or a person who has official position, the penalty is increased one-third rate".

The subject of this crime is medicine in accordance with the lawful cause of this Article. The crime occurs when the medicine is produced or sold by placing at risk someone's life and health. A medicine to be able to place at risk persons' life and health is enough for the medicine to be able to be the subject of this crime. Quack remedy (fake medicine), original medicine or generics medicine can be the subject of this crime if the conditions occur. Offender of the crime can be anyone in accordance with the Article $187 / \mathrm{I}$ as any specialty for the offender is not searched for the crime. As producing or selling medicine is an abstract endangerment, the judge have to search only whether the medicine is placing at risk persons' life and health or not. If the judge determines that the medicine enable placing at risk persons' life and health it is enough for the offender to be sentenced. The crime to produce or to sell medicine by placing at risk persons' life and health can be committed only deliberately. Finally contradiction to law is another condition for the crime. So action occurs lawful and offender cannot be sentenced if there is a reason for lawfulness in accordance with the Article 24 et seq. of the Turkish Criminal Coder [18].

\section{CONCLUSION}

Medicines have an important role for human life in order for humans to be protected from illnesses. As the Turkish legislator takes into account this particularity of medicines, it is illegal to sell medicines online in Turkish law. Making a contract for the sale of medicine online is null and void. So the basis of civil liability of seller is tort that is regulated in the Code of Obligations no 6098. The victim has to prove the conditions of liability for an action for damages. On the other hand, consumers cannot buy a medicinal product online with a right of withdrawal as the sales contract via internet related to the medicine is invalid. 
It is argued in the doctrine that the damaged party can bring an action based on the liability for danger about the liability of the manufacturer of the original because of sale of medicine via internet. So the liability of danger which is regulated generally in the Code of Obligations no 6098 can be accepted as the legal basis for the responsibility of producer of medicine.

Protection of the owners of the pharmaceutical trademarks because of the sale of trademarked medicines on internet without their permission is granted in Turkish law. In this regard, registered pharmaceutical trademarks are protected according to the Act on the Industrial Property no 6769. Unregistered pharmaceutical trademarks are protected according to the provisions related to the unfair competition of the Turkish Commercial Code no 6102.

${ }^{4}$ See Demir, Mehmet: İlaç Kullanımı Sonucunda Doğan Zararlardan İlaç Üreticisinin, Eczacının ve Hekimin ${ }^{1}$ Sorumluluğu, Türkiye Barolar Birliği Dergisi, Vol. 22, No. 89, Y. 2010, p. 96 et seq.

4 See Döner, 361 et seq.

4 See Altunkaş, p. 829 et seq. ${ }^{3}$

Finally, criminal liability for sales of medicines based on internet is granted in Turkish law, as well. Producers, holders, sellers and transferors of substance that involves poison and depends on permission to produce, to hold or to sell without permission are sentenced to imprisonment. 


\section{REFERENCES}

Akçaal, Mehmet : 6098 Sayılı Türk Borçlar Kanunu Çerçevesinde İlaç Üreticisinin Hukuki Sorumluluğu, Ankara Barosu Dergisi, 2012/3, page 251-290.

Akınc1, Şahin : Borçlar Hukuku Bilgisi, Genel Hükümler, 10th Edition Konya 2017.

Akıntürk, Turgut / Ateş Karaman, Derya : Borçlar Hukuku, Genel Hükümler, Özel Borç İlişkileri, 20th. Edition, İstanbul 2013.

Akipek, Jale G. / Akıntürk, Turgut / Ateş Karaman, Derya : Türk Medeni Hukuku, Vol.: 1, 9th Edition, İstanbul 2012.

Akkanat, Halil : İlaç Kullanımından Kaynaklanan Zararlardan Sorumluluk Açısından HastaHekim-Üretici İlişkileri, Erciyes Üniversitesi Hukuk Fakültesi, I. Sağlık Hukuku Sempozyumu, 08-09 Mayıs 2009 Kayseri, Vol. 1, No. 1, Pp. 75-84.

Altunkaş, Aysun : Kişilerin Hayatını ve Sağlığını Tehlikeye Sokacak Biçimde İlaç Yapma veya Satma Suçu (TCK m. 187), Marmara Üniversitesi Hukuk Fakültesi Hukuk Araştırmaları Dergisi, 2013/II, Pp. 829-870.

Antalya, O. Gökhan : Borçlar Hukuku, Genel Hükümler, Vol.: 1, İstanbul 2013.

Arkan, Sabih : Ticari İşletme Hukuku, 17th Edition, Ankara 2012.

Baş, Başak : İlaçta Zorunlu Patent Lisans1, Ankara Barosu Dergisi, Vol. 69, No. 3, Y. 2011, Pp. 105-126

Başpınar, Veysel : İlaç Üreticisinin Hukuki Sorumluluğu, İlaç Hukuku, Erciyes Üniversitesi Hukuk Fakültesi I. Sağlık Hukuku Sempozyumu 8-9 Mayıs 2009-Kayseri, Vol. 1. No. 1, Pp. 85-110.

Demir, Mehmet : İlaç Kullanımı Sonucunda Doğan Zararlardan İlaç Üreticisinin, Eczacının ve Hekimin Sorumluluğu, Türkiye Barolar Birliği Dergisi, Vol. 22, No. 89, Y. 2010, Pp. 96128.

Doğan, Cahid : İlaç Kullanımı Dolayısıyla Ortaya Çıkan Zararlardan Cezai Sorumluluk, II. Sağlı Hukuku Kurultayı, 7-8 Kasım 2008 Ankara, Ankara Barosu Yayınları, 2009, Pp. 411454.

Doğan, Murat : Eczacının Tazminat Sorumluluğu, (http://www.kazanci.com/kho2/hebb/files/makale-muratdogan-9.htm.), (Date of Access:12.5.2015).

Döner, İsa : İlaç Sahtekarlığı Suçları (TCK m. 186 - TCK m. 187), İlaç Hukuku, Editörler: Murat Şen / Ahmet Başözen, Erciyes Üniversitesi Hukuk Fakültesi I. Sağlık Hukuku Sempozyumu, 08-09 Mayıs 2009, Kayseri, Pp. 361-389.

Dural, Mustafa / Ögüz, Tufan : Türk Özel Hukuku, Kişiler Hukuku, Vol.: 2, 10 th. Edition, İstanbul 2010. 
Eren, Fikret : Borçlar Hukuku Genel Hükümler, 22th. Edition, Ankara 2017.

Honsell, Heinrich / Vogt, Peter Nedim / Wiegand, Wolfgang : Basler Kommentar, Obligationenrecht I Art. 1-519 OR, 6th Edition, Basel 2015.

Guhl, Theo, Das Schweizerische Obligationenrecht, 3th Edition, Zürich 1944.

Keskin, A. Dilşad : Objektif Manevi Zarar Teorisi Açısından Manevi Tazminat, Ankara 2016.

Kılıçoğlu, Ahmet M. : Borçlar Hukuku, Genel Hükümler, 17th Edition, Ankara 2013.

Koca, Mahmut : İlaç Kullanımından Doğan Zararlardan Cezai Sorumluluk, İlaç Hukuku, Editörler: Murat Şen / Ahmet Başözen, Erciyes Üniversitesi I. Sağlık Hukuku Sempozyumu, 08-09 May1s 2009, Kayseri, Pp. 321-359.

Oğuzman, M. Kemal / Öz, M. Turgut : Borçlar Hukuku Genel Hükümler, Vol: 2, 12th Edition, İstanbul 2016.

Oğuzman, M. Kemal / Seliçi, Özer / Oktay-Özdemir, Saibe : Kişiler Hukuku, Gerçek ve Tüzel Kişiler, 12th Edition, İstanbul 2012.

Petek, Hasan : İlaç Üreticisinin Hukuki Sorumluluğu, Ankara 2009.

Reisoğlu, Safa : Borçlar Hukuku, Genel Hükümler, 23th Edition, İstanbul 2012.

Schönenberger, Wilhelm / Gauch, Peter : Schweizerisches Obligationenrecht, 38th Edition, Zürich 1990.

Tandoğan, Halûk : Türk Mes’uliyet Hukuku, 2 th Edition, İstanbul 2010.

Tekinalp, Ünal : Fikri Mülkiyet Hukuku, İstanbul 2012

Tekinay, Selahattin S. / Akman, Sermet / Burcuoğlu, Haluk / Altop, Atilla : Borçlar Hukuku, Genel Hükümler, 7th Edition, İstanbul 1993.

Tiftik, Mustafa : Tehlike Sorumluluğunun Ayırıcı Özellikleri ve Türk Hukukunda Tehlike Sorumluluklarının Genel Kural İle Düzenlenmesi Sorunu, Erzurum 1997.

von Tuhr, Andreas : Borçlar Hukukunun Umumî Kısmı (Translator: Cevat Edge), Vol.: 1-2, 2th. Edition, Ankara 1983.

Yenerer Çakmut, Özlem : Taklit - Sahte İlaç Kavramı ve Türk Ceza Yasası'nda İlaç Sektörünü İlgilendiren Suçlar (TCK m. 186-187), İlaç Hukuku ve Etik Anlayış1, Sempozyum No: 2, Marmara Üniversitesi, 01.06.2007, Pp. 126-150.

Yücel, Özge : Türk Borçlar Kanununa Göre Genel Tehlike Sorumluluğu, Ankara 2014. 